\title{
Synthesis and Identification of a New Steroid, 24-Ethyl-5 $\alpha$-cholest-24(28)Z-en-3-one in the Seeds of Foxtail Millet
}

\author{
Yasuhisa Narumi*1, Tsuyoshi Watanabe*2, Takahiro Noguchi*2, Bun-ichi AbE*1, \\ Shozo Fujioka*3, Takao Yокота ${ }^{* 4}$, and Suguru Takatsuto*1 \\ * 1 Department of Chemistry, Joetsu University of Education \\ (1, Yamayashiki-machi, Joetsu-shi, Niigata-ken 943-8512) \\ *2 Tama Biochemical Co. Ltd. \\ (2-7-1, Nishishinjuku, Shinjuku-ku, Tokyo 163-0704) \\ * 3 Plant Functions Laboratory, The Institute of Physical and Chemical Research (RIKEN) \\ (2-1, Hirosawa, Wako-shi, Saitama-ken 351-0198) \\ * 4 Department of Biosciences, Teikyo University \\ (1-1, Toyosatodai, Utsunomiya-shi, Tochigi-ken 320-8551)
}

\begin{abstract}
Study was made to determine the structures of three minor $5 \alpha$-steroidal 3-ones detected in the seeds of foxtail millet (Setaria italica Beauv.). For this purpose, 24 -ethyl-5 $\alpha$-cholest-24(28) $Z$-en-3one and its carbon-carbon double bond isomers were synthesized from isofucosterol. Based on direct GCMS comparison with the synthetic samples, one steroid was found here for the first time to have the structure, 24-ethyl-5 $\alpha$-cholest-24(28) $Z$-en-3-one. Two other minor steroids were identified as $24 \xi$-ethyl$5 \alpha$-cholesta-7,22E-dien-3-one and $24 \xi$-ethyl-5 $\alpha$-cholest-7-en-3-one.
\end{abstract}

Key words : Setaria italica Beauv., 24-ethyl-5 $\alpha$-cholest-24(28)Z-en-3-one, isofucosterol, $24 \xi$-ethyl$5 \alpha$-cholesta-7,22E-dien-3-one, $24 \xi$-ethyl-5 $\alpha$-cholest-7-en-3-one

\section{Introduction}

In our investigation of brassinosteroid precursors, we recently reported the presence of seven

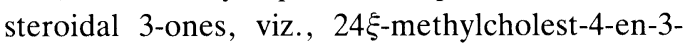

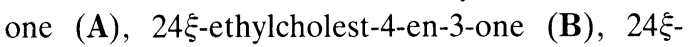
ethylcholesta-4,22E-dien-3-one (C), 24 $\xi$-methyl$5 \alpha$-cholestan-3-one (D), $24 \xi$-ethyl-5 $\alpha$-cholestan-3one (E), $24 \xi$-ethyl-5 $\alpha$-cholest-22E-en-3-one $(\mathbf{F})$ and 24-ethylcholesta-4,24(28)Z-dien-3-one (G) (Fig. 1), in the seeds of wheat (Triticum aestivum L.) and foxtail millet (Setaria italica Beauv.) ${ }^{1)}$. In the seeds of foxtail millet, three additional minor steroids $\mathbf{X}_{1}, \mathbf{X}_{\mathbf{2}}$ and $\mathbf{X}_{3}$ were detected by GC-MS analysis, but their structures remained undetermined, because of the lack of authentic samples ${ }^{2}$. In the mass spectrum (MS) of the steroid $\mathbf{X}_{\mathbf{1}}$, a molecular ion at $m / z 412$ was observed along with

Corresponding author: Suguru TAKATSUTO ions at $\mathrm{m} / \mathrm{z} 314,299,271,258,245,244,231,229$, $217,203,189,175,163,149,135,123$ and 109. The MS data suggest its structure to be 24 -ethyl- $5 \alpha$ cholestan-3-one with one double bond at the C24(25), C-24(28) $E$ or C-24(28) $Z$ position, because a characteristic fragment ion due to McLafferty type rearrangement was observed at $m / z 314$ as a base peak. On the other hand, based on the reported MS data ${ }^{3}$, the steroids $\mathbf{X}_{2}$ and $\mathbf{X}_{3}$ are likely to be $24 \xi$-ethyl-5 $\alpha$-cholest-7-en-3-one and $24 \xi$-ethyl-5 $\alpha$-cholesta-7,22E-dien-3-one, respectively.

To identify the steroid $\mathbf{X}_{\mathbf{1}}$, we synthesized at first a mixture of the above-mentioned possible double bond isomers, then synthesized the most plausible candidate and compared it with the natural product. For the identification of the steroids $\mathbf{X}_{\mathbf{2}}$ and $\mathbf{X}_{3}$, we synthesized a mixture containing $24 \xi$ ethyl-5 $\alpha$-cholest-7-en-3-one and $24 S$-ethyl-5 $\alpha$ cholesta-7,22E-dien-3-one from a $5 \alpha-\Delta^{7}$-sterol 

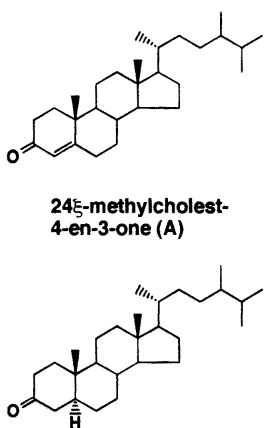

$24 \xi$-methyl-5 $\alpha$ cholestan-3-one (D)

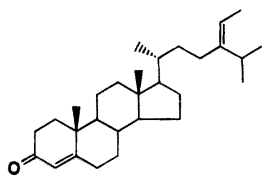

24-ethylcholesta4,24(28)Z-dien-3-one (G)

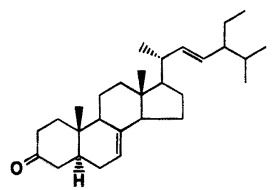

$24 \xi-$-ethyl-5 $\alpha$-cholesta 7,22E-dien-3-one $\left(X_{3}\right)$

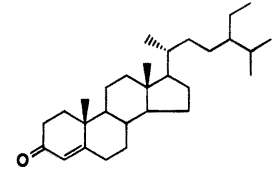

$24 \xi$-ethylcholest4-en-3-one (B)

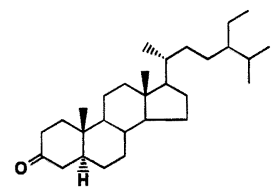

$24 \xi$-ethyl-5 $\alpha$ cholestan-3-one (E)

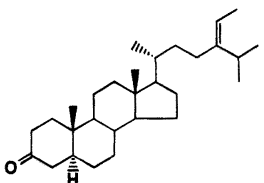

24-ethyl-5 $\alpha$-cholest24(28)Z-en-3-one $\left(X_{1}\right)$
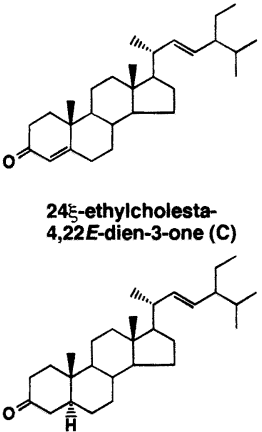

$24 \xi-$-ethyl-5 $\alpha$-cholest22E-en-3-one (F)

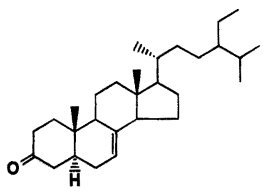

$24 \xi$-ethyl-5 $\alpha$-cholest7-en-3-one $\left(X_{2}\right)$

Fig. 1 Structures of Steroidal 3-ones Found in the Seeds of Foxtail Millet.

fraction. In this paper, we report details of these syntheses and the identification of the minor steroids $\mathbf{X}_{1}, \mathbf{X}_{2}$ and $\mathbf{X}_{3}$ found in the seeds of foxtail millet.

\section{Experimental}

\section{$2 \cdot 1$ Analytical Methods}

Melting points were determined under a hotstage microscope (Yazawa micro melting point apparatus) and not corrected. ${ }^{1} \mathrm{H}-\mathrm{NMR}$ spectra were recorded on a JEOL JMN-A400 (400 MHz) or a JEOL JMN-ECP500 (500 MHz) spectrometer in a deuterio-chloroform solution using tetramethylsilane as an internal standard. EI-MS and HR-EI-MS were measured with a JEOL SX-102 mass spectrometer at $70 \mathrm{eV}$.

\section{$\mathbf{2} \cdot 2$ GC-MS Analysis}

GC-MS analysis was performed with a gas chromatograph-mass spectrometer (GC-MS QP5000 , Shimadzu Corporation) under the following condition : capillary column, DB-1 $(30 \mathrm{~m} \times 0.25$ mm i.d., $0.25 \mu \mathrm{m}$ film thickness, J \& W Scientific) ; column temp., elevated from $270^{\circ} \mathrm{C}$ to $300^{\circ} \mathrm{C}$ at a rate of $2^{\circ} \mathrm{C} / \mathrm{min}$, then $300^{\circ} \mathrm{C}$ for $5 \mathrm{~min}$; injection, split ; split ratio, $70: 1$; injection temp., $300^{\circ} \mathrm{C}$, interface temp., $280^{\circ} \mathrm{C}$; carrier gas, helium ; carrier gas pressure, $100 \mathrm{kPa}$; total flow rate, 52.6 $\mathrm{mL} / \mathrm{min}$; column flow rate, $0.7 \mathrm{~mL} / \mathrm{min}$; ionization, electron impact $(70 \mathrm{eV})$; scan interval, 0.5 sec. ; mass range, $m / z 100 \sim 550$.

2.3 Synthesis of a Mixture Containing Possible Carbon-carbon Double Bond Isomers of the Steroid $\mathbf{X}_{1}$

$2 \cdot 3 \cdot 1$ Preparation of $3 \beta$-acetoxycholest-5-en24-one 2

A sterol fraction containing isofucosterol was obtained as its acetate from the broad bean pollen, as already reported ${ }^{4}$. The steryl acetate mixture $(1.0 \mathrm{~g})$ in tetrahydrofuran (THF) $(20 \mathrm{~mL})$ and $\mathrm{H}_{2} \mathrm{O}$ $(2 \mathrm{~mL})$ was treated with osmium tetroxide $(100$ $\mathrm{mg})$ and $N$-methylmorpholine $N$-oxide $(1.20 \mathrm{~g})$ at room temperature overnight. The work-up (ethyl acetate, EtOAc) gave a mixture of 24, 28-diols 1 $(0.96 \mathrm{~g})$, which in THF $(15 \mathrm{~mL})$ was treated with a solution of sodium periodate $(1.02 \mathrm{~g})$ in $\mathrm{H}_{2} \mathrm{O}(5$ $\mathrm{mL}$ ) at room temperature for $2.5 \mathrm{~h}$. The work-up 
(EtOAc) and chromatography on a column of silica gel $(2.0 \mathrm{~cm}$ i.d. $\times 25 \mathrm{~cm}, 70 \sim 230$ mesh, Merck) with $4.8 \%$ EtOAc/hexane provided a known $3 \beta$-acetoxycholest-5-en-24-one $2(0.39 \mathrm{~g})$, $\mathrm{mp} 117 \sim 118^{\circ} \mathrm{C}$ (from methanol, $\mathrm{MeOH}$ ) [lit. ${ }^{5}$, $\mathrm{mp}$ $128^{\circ} \mathrm{C}$ (solvent was not specified)]. Although our sample had lower melting point than the reported data, it was found to be a single compound by GCMS. Its spectral data were as follows : ${ }^{1} \mathrm{H}-\mathrm{NMR}$ $(500 \mathrm{MHz}) \delta: 0.674\left(3 \mathrm{H}, \mathrm{s}, 18-\mathrm{H}_{3}\right), 0.915(3 \mathrm{H}, \mathrm{d}, J$ $\left.=6.50 \mathrm{~Hz}, 21-\mathrm{H}_{3}\right), 1.016\left(3 \mathrm{H}, \mathrm{s}, 19-\mathrm{H}_{3}\right), 1.091$ $\left(6 \mathrm{H}, \mathrm{d} \times 2, J=6.83 \mathrm{~Hz}, 26-\mathrm{H}_{3}\right.$ and $\left.27-\mathrm{H}_{3}\right), 2.033$ $(3 \mathrm{H}, \mathrm{s}$, acetyl), $2.610(1 \mathrm{H}$, sept, $J=6.83 \mathrm{~Hz}, 25-$ H), $4.603(1 \mathrm{H}, \mathrm{m}, 3 \alpha-\mathrm{H}), 5.374(1 \mathrm{H}, \mathrm{m}, 6-\mathrm{H})$. EIMS $m / z$ (rel. int., \%) : $382\left(\mathrm{M}^{+}-60,100\right), 367$ (15), 340 (3), 339 (3), 296 (14), 281 (6), 274 (6), 261 (11), 255 (16), 253 (7), 243 (3), 228 (6), 213 (16). HR-EI-MS ; Calcd. for $\mathrm{C}_{27} \mathrm{H}_{42} \mathrm{O}\left(\mathrm{M}^{+}-60\right)$ : 382.3238, Found : 382.3229 .

$2 \cdot 3 \cdot 2$ Preparation of $3 \beta$-hydroxycholest-5-en24-one 3

The steroid $2(72 \mathrm{mg})$ in THF $(5 \mathrm{~mL})$ was treated with $5 \% \mathrm{KOH} / \mathrm{MeOH}(1 \mathrm{~mL})$ at room temperature for $3 \mathrm{~h}$. The work-up (chloroform) gave the title compound $3(61 \mathrm{mg})$, mp 136 137 ${ }^{\circ} \mathrm{C}$ (from $\mathrm{MeOH}),{ }^{1} \mathrm{H}-\mathrm{NMR}(500 \mathrm{MHz}) \delta: 0.676(3 \mathrm{H}, \mathrm{s}, 18-$ $\left.\mathrm{H}_{3}\right), 0.915\left(3 \mathrm{H}, \mathrm{d}, J=6.52 \mathrm{~Hz}, 21-\mathrm{H}_{3}\right), 1.007(3 \mathrm{H}$, s, $\left.19-\mathrm{H}_{3}\right), 1.090\left(6 \mathrm{H}, \mathrm{d} \times 2, J=6.85 \mathrm{~Hz}, 26-\mathrm{H}_{3}\right.$ and 27- $\left.\mathrm{H}_{3}\right), 2.610(1 \mathrm{H}$, sept, $J=6.85 \mathrm{~Hz}, 25-\mathrm{H}), 3.521$ $(1 \mathrm{H}, \mathrm{m}, 3 \alpha-\mathrm{H}), 5.352(1 \mathrm{H}, \mathrm{m}, 6-\mathrm{H})$. EI-MS $m / z$ : $400\left(\mathbf{M}^{+}, 100\right), 385(19), 382$ (63), 367 (27), 357 (7), 340 (7), 314 (45), 299 (18), 296 (11), 289 (27), 281 (15), 273 (13), 271 (23), 255 (28), 231 (15), 213 (41). HR-EI-MS ; Calcd. for $\mathrm{C}_{27} \mathrm{H}_{44} \mathrm{O}_{2}\left(\mathrm{M}^{+}\right)$: 400.3343, Found : 400.3336.

$2 \cdot 3 \cdot 3$ Preparation of a mixture of fucosterol and its double bond isomers 6

The steroid $3(90 \mathrm{mg})$ in dichloromethane $\left(\mathrm{CH}_{2} \mathrm{Cl}_{2}\right)(5 \mathrm{~mL})$ was treated with 2,3-dihydropyran $(0.5 \mathrm{~mL})$ and $p$-toluenesulfonic acid monohydrate $(5 \mathrm{mg})$ at room temperature for $1 \mathrm{~h}$. The work-up $\left(\mathrm{CH}_{2} \mathrm{Cl}_{2}\right)$ gave a tetrahydropyranyl ether $4(91 \mathrm{mg}), \mathrm{mp} 133 \sim 134^{\circ} \mathrm{C}$ (from $\mathrm{MeOH}$ ), which in THF ( $5 \mathrm{~mL}$ ) was treated with $\mathrm{ca} .3 \mathrm{M}$ solution of ethylmagnesium bromide in diethyl ether $\left(\mathrm{Et}_{2} \mathrm{O}\right)$ (1 mL, Tokyo Kasei) under argon at room temperature for $1 \mathrm{~h}$. After the work-up (EtOAc), the resulting alcohol 5 in pyridine $(3 \mathrm{~mL})$ was treated with phosphorus oxychloride $(0.5 \mathrm{~mL})$ at room temperature for $3 \mathrm{~d}$. After the work-up
(EtOAc), a product in THF (4 mL) and $\mathrm{MeOH}(2$ $\mathrm{mL})$ was treated with $2 \mathrm{M} \mathrm{HCl}(0.3 \mathrm{~mL})$ at room temperature for $2 \mathrm{~h}$. The work-up (EtOAc) and chromatography on a silica gel column $(2.0 \mathrm{~cm}$ i.d. $\times 20 \mathrm{~cm}$ ) with $17 \% \mathrm{EtOAc} /$ hexane provided a sterol mixture of the title compounds $6(50 \mathrm{mg})$.

A small portion of the mixture was analyzed by GC-MS after trimethylsilylation. The relative retention time $\left(\mathrm{Rt}_{\mathrm{R}}\right)$ of each sterol trimethylsilyl (TMS) ether to the $t_{R}(10.57 \mathrm{~min})$ of cholesterol TMS ether was determined and the composition was obtained by total ion chromatogram. The mixture was found to contain TMS ethers of 24ethylcholesta-5,23Z-dien-3 $\beta$-ol $\left(\mathrm{Rt}_{\mathrm{R}} 1.25,5.4 \%\right)$, 24-ethylcholesta-5,23E-dien-3 $\beta$-ol $\left(\mathrm{Rt}_{\mathrm{R}} 1.26,10.0\right.$ $\%)$, fucosterol ( $\left.\mathrm{Rt}_{\mathrm{R}} 1.29,27.1 \%\right)$, isofucosterol $\left(\mathrm{Rt}_{\mathrm{R}} 1.31,16.2 \%\right)$ and 24-ethyldesmosterol $\left(\mathrm{Rt}_{\mathrm{R}}\right.$ $1.36,41.3 \%)$. The MS data of the former two were the same, $m / z: 484\left(\mathrm{M}^{+}, 8\right), 469(7), 394(7), 386$ (7), 379 (10), 372 (8), 355 (11), 343 (51), 283 (68), 253 (40), 243 (12), 241 (20), 227 (12), 215 (23), 213 (16), 173 (34), 159 (53), 145 (42), 133 (100), 129 (96), 121 (39), 119 (61). The MS data of the latter three were the same, $m / z: 484\left(\mathrm{M}^{+}, 6\right), 469(4)$, 394 (4), 386 (50), 379 (6), 371 (14), 355 (7), 343 (10), 296 (47), 281 (37), 257 (17), 255 (12), 253 (21), 227 (8), 213 (14), $211(20), 173$ (14), 161 (18), 159 (26), 147 (24), 145 (28), 133 (27), 129 (100), 121 (30), 119 (50).

The TMS ethers of fucosterol and isofucosterol were identified based on direct comparison with authentic samples (fucosterol was purchased from Wako and isofucosterol was obtained as described later). 24-Ethyldesmosterol TMS ether was identified based on analysis of its MS data, which was superimposable to those of the TMS ethers of fucosterol and isofucosterol. The structure of each TMS ether of 24-ethylcholesta-5,23Z-dien-3 $\beta$-ol and 24-ethylcholesta-5,23E-dien-3 $\beta$-ol is based on both the MS data and the mechanism of the abovementioned dehydration. The assignment of $23 E$ and $23 Z$-isomers is reversible and tentative.

$2 \cdot 3 \cdot 4$ Preparation of a mixture of 24-ethylcholesta-4,23E-, 4,23Z-, 4,24(28)E-, 4, 24(28) $Z$ - and 4, 24(25)-dien-3-ones 7

The sterol mixture $6(50 \mathrm{mg})$ in 1-methyl-4piperidone $(1.4 \mathrm{~mL})$ and toluene $(5 \mathrm{~mL})$ was treated with aluminum isopropoxide $(0.15 \mathrm{~g})$ at $110^{\circ} \mathrm{C}$ under argon for $1 \mathrm{~h}$. After the work-up $(\mathrm{EtOAc})$, a product was applied onto three plates 
of silica gel $(20 \mathrm{~cm} \times 20 \mathrm{~cm}, 0.5 \mathrm{~mm}$ thickness, Merck) and they were developed with $17 \%$ EtOAc/hexane. The silica gel band with $\mathrm{R}_{\mathrm{F}} 0.30 \sim$ 0.37 was scraped off, eluted with EtOAc and concentrated to provide a mixture of the title compounds $7(29 \mathrm{mg})$. The mixture was analyzed by GC-MS to contain 24-ethylcholesta-4, 23Zdien-3-one $\left(\mathrm{Rt}_{\mathrm{R}} 1.36,6.1 \%\right)$, 24-ethylcholesta-4, $23 E$-dien-3-one $\left(\mathrm{Rt}_{\mathrm{R}} 1.37,8.3 \%\right), \quad 24$-ethylcholesta-4, 24(28)E-dien-3-one ( $\left.\mathrm{Rt}_{\mathrm{R}} 1.41,29.3 \%\right)$, 24-ethylcholesta-4, 24(28)Z-dien-3-one ( $\mathrm{Rt}_{\mathrm{R}} 1.43$, $16.3 \%$ ) and 24-ethylcholesta-4, 24(25)-dien-3-one $\left(R t_{R} 1.48,40.0 \%\right)$. The assignment of the former two is tentative and that of the latter three is based on the composition and the $\mathrm{Rt}_{\mathrm{R}}$ of the starting sterol mixture. The MS data of the former two were the same, $m / z: 410\left(\mathrm{M}^{+}, 37\right), 395$ (7), 312 (11), 299 (51), 281 (54), 269 (100), 253 (10), 241 (7), 229 (13), 215 (10), 203 (21), 185 (20), 175 (56), 161 (47), 149 (96), 135 (52), 121 (55), 107 (64). The MS data of the latter three were the same, $\mathrm{m} / \mathrm{z}$ : $410\left(\mathrm{M}^{+}, 12\right), 395$ (4), 313 (100), 312 (90), 297 (72), $283(5), 268(32), 256(15), 243$ (27), 231 (42), 227 (60), 201 (13), 189 (20), 173 (16), 159 (18), 147 (33), 133 (38), 124 (46), 105 (55).

$2 \cdot 3 \cdot 5$ Preparation of a mixture of 24-ethyl- $5 \alpha$ cholest-23E-, 23Z-, 24(28)E-, 24(28)Zand 24(25)-en-3-ones 8

The enone mixture $7(20 \mathrm{mg})$ in THF $(5 \mathrm{~mL})$ and ethanol ( 2 drops) was treated with a mixture of lithium $(25 \mathrm{mg})$ and liquid ammonia $(10 \mathrm{~mL})$ at $-78^{\circ} \mathrm{C}$ under argon for $1 \mathrm{~h}$. Ammonium chloride $(1.0 \mathrm{~g})$ was added to the mixture and ammonia was evaporated at room temperature. After the workup (EtOAc), a product was applied onto two plates of silica gel $(20 \mathrm{~cm} \times 20 \mathrm{~cm})$ and they were developed with $17 \% \mathrm{EtOAc} /$ hexane. The silica gel band with $R_{F} 0.43 \sim 0.49$ was scraped off, eluted with EtOAc and concentrated to give a mixture of the title compounds $8(10 \mathrm{mg})$. The mixture was analyzed by GC-MS to contain 24-ethyl-5 $\alpha$ cholest-23Z-en-3-one ( $\left.\mathrm{Rt}_{\mathrm{R}} 1.23,5.8 \%\right)$, 24-ethyl$5 \alpha$-cholest-23E-en-3-one ( $\left.\mathrm{Rt}_{\mathrm{R}} 1.24,11.5 \%\right), 24$ ethyl-5 $\alpha$-cholest-24(28) $E$-en-3-one ( $\mathrm{Rt}_{\mathrm{R}} 1.28,26.3$ $\%)$ 24-ethyl-5 $\alpha$-cholest-24(28)Z-en-3-one $\left(\mathrm{Rt}_{\mathrm{R}}\right.$ $1.30,21.5 \%$ ) and 24 -ethyl-5 $\alpha$-cholest-24(25)-en-3one $\left(\mathrm{Rt}_{\mathrm{R}} 1.35,34.9 \%\right)$. The assignment of the former two is tentative and that of the latter three is based on the composition and the $\mathrm{Rt}_{\mathrm{R}}$ of the starting sterol mixture. The MS data of the former two were the same, $m / z: 412\left(\mathrm{M}^{+}, 5\right), 397(5), 314$ (17), 301 (22), 299 (29), 283 (44), 271 (100), 257 (9), 255 (6), 245 (5), 231 (17), 217 (8), 215 (9), 205 (11), 191 (30), 187 (17), 177 (14), 175 (17), 163 (21), 161 (22), 159 (14), 151 (19), 149 (28), 147 (16), 145 (14), 137 (22), 135 (34), 133 (21), 123 (87), 121 (40), 109 (59), 107 (51). The MS data of the latter three were the same, $m / z: 412\left(\mathrm{M}^{+}, 3\right)$, 397 (1), 314 (100), 299 (42), 285 (4), 271 (21), 258 (10), 245 (12), 244 (10), 233 (11), 231 (23), 229 (14), 217 (12), 215 (7), 203 (7), 189 (6), 187 (5), 175 (7), 163 (13), 161 (13), 149 (13), 147 (11), 145 (10), 135 (21), 133 (11), 123 (25), 121 (26), 119 (14), 109 (28), 107 (28).

\section{$\mathbf{2} \cdot 4$ Isolation of Isofucosterol 9}

The above-mentioned steryl acetate mixture ${ }^{3)}$ $(0.57 \mathrm{~g})$ in a minimum amount of $1 \% \mathrm{Et}_{2} \mathrm{O} / \mathrm{CH}_{2} \mathrm{Cl}_{2}$ was applied onto a $10 \%$ silver nitrate $\left(\mathrm{AgNO}_{3}\right)$ silica gel column $(2.0 \mathrm{~cm}$ i.d. $\times 33 \mathrm{~cm})$ wrapped around in an aluminum foil. Elution was conducted with $1 \% \mathrm{Et}_{2} \mathrm{O} / \mathrm{CH}_{2} \mathrm{Cl}_{2}$. Each fraction was collected in the amount of $20 \mathrm{~mL}$ and monitored by $\mathrm{AgNO}_{3}$-TLC using $3 \% \mathrm{Et}_{2} \mathrm{O} / \mathrm{CH}_{2} \mathrm{Cl}_{2}$ as a developing solvent. Fraction 6 (199 mg) was found to be a single spot by $\mathrm{AgNO}_{3}$-TLC and determined by GC-MS to contain isofucosteryl acetate, $\mathrm{mp} 133$ $\sim 134^{\circ} \mathrm{C}$ (from $\mathrm{MeOH}$ ) (lit..$^{6)}$, mp $137 \sim 139^{\circ} \mathrm{C}$ ). Its ${ }^{1} \mathrm{H}-\mathrm{NMR}(500 \mathrm{MHz})$ and EI-MS data were identical with the reported data ${ }^{6}$.

As described above, isofucosteryl acetate (110 $\mathrm{mg}$ ) was saponified to afford isofucosterol 9 (98 $\mathrm{mg}$ ), mp $134 \sim 135^{\circ} \mathrm{C}$ (from $\mathrm{MeOH}$ ) (lit. ${ }^{6}$, mp 139 $\left.\sim 140^{\circ} \mathrm{C}\right)$. Its ${ }^{1} \mathrm{H}-\mathrm{NMR}(500 \mathrm{MHz})$ and $\mathrm{MS}$ data were identical with the reported data ${ }^{6}$.

\section{$2 \cdot 5$ Synthesis of 24-ethyl-5 $\alpha$-cholest-24(28) Z-en-3-one 11}

As described above, isofucosterol 9 (44 mg) was subjected to Oppenauer oxidation to afford 24ethylcholesta-4, 24(28)Z-dien-3-one 10 (19 mg) : mp $66 \sim 68^{\circ} \mathrm{C}$ (from $\left.\mathrm{MeOH}\right),{ }^{1} \mathrm{H}-\mathrm{NMR}(400 \mathrm{MHz})$ $\delta: 0.714\left(3 \mathrm{H}, \mathrm{s}, 18-\mathrm{H}_{3}\right), 0.943(3 \mathrm{H}, \mathrm{d}, J=6.84 \mathrm{~Hz}$, $\left.21-\mathrm{H}_{3}\right), 0.976\left(6 \mathrm{H}, \mathrm{d} \times 2, J=7.33 \mathrm{~Hz}, 26-\mathrm{H}_{3}\right.$ and $\left.27-\mathrm{H}_{3}\right), 1.182\left(3 \mathrm{H}, \mathrm{s}, 19-\mathrm{H}_{3}\right), 1.591(3 \mathrm{H}, \mathrm{d}, J=6.84$ $\left.\mathrm{Hz}, 29-\mathrm{H}_{3}\right), 2.831(1 \mathrm{H}$, sept, $J=6.84 \mathrm{~Hz}, 25-\mathrm{H})$, $5.105(1 \mathrm{H}, \mathrm{q}, J=6.84 \mathrm{~Hz}, 28-\mathrm{H}), 5.724(1 \mathrm{H}, \mathrm{s}, 4-$ $\mathrm{H})$. Its MS data by GC-MS was the same as described above. HR-EI-MS ; Calcd. for $\mathrm{C}_{29} \mathrm{H}_{46} \mathrm{O}$ $\left(\mathrm{M}^{+}\right): 410.3551$, Found : 410.3553 .

As described above, the steroid $\mathbf{1 0}(15 \mathrm{mg})$ was subjected to Birch reduction to give 24-ethyl-5 $\alpha$ - 
cholest-24(28)Z-en-3-one $11(9.5 \mathrm{mg}): \mathrm{mp} 151 \sim$ $151.5^{\circ} \mathrm{C}$ (from $\left.\mathrm{MeOH}\right),{ }^{1} \mathrm{H}-\mathrm{NMR}(400 \mathrm{MHz}) \delta$ : $0.681\left(3 \mathrm{H}, \mathrm{s}, 18-\mathrm{H}_{3}\right), 0.935(3 \mathrm{H}, \mathrm{d}, J=6.34 \mathrm{~Hz}, 21-$ $\left.\mathrm{H}_{3}\right), 0.974\left(6 \mathrm{H}, \mathrm{d} \times 2, J=6.83 \mathrm{~Hz}, 26-\mathrm{H}_{3}\right.$ and $27-$ $\left.\mathrm{H}_{3}\right), 1.007\left(3 \mathrm{H}, \mathrm{s}, 19-\mathrm{H}_{3}\right), 1.589(3 \mathrm{H}, \mathrm{d}, J=6.83$ $\left.\mathrm{Hz}, 29-\mathrm{H}_{3}\right), 2.829(1 \mathrm{H}$, sept, $J=6.83 \mathrm{~Hz}, 25-\mathrm{H})$, $5.104(1 \mathrm{H}, \mathrm{q}, J=6.83 \mathrm{~Hz}, 28-\mathrm{H})$. Its MS data by GC-MS was the same as described above. HR-EIMS ; Calcd. for $\mathrm{C}_{29} \mathrm{H}_{48} \mathrm{O}\left(\mathrm{M}^{+}\right): 412.3707$, Found : 412.3711.

\subsection{Preparation of a Mixture Containing} 24S-ethyl-5 $\alpha$-cholesta-7,22E-dien-3-one and $24 \xi$-ethyl-5 $\alpha$-cholest-7-en-3-one

As previously described ${ }^{7}$, a $5 \alpha-\Delta^{7}$-sterol fraction containing spinasterol and $24 \xi$-ethyl-5 $\alpha$-cholest-7en-3 $\beta$-ol was obtained from the Amaranthus seeds. The sterol fraction $(12 \mathrm{mg})$ in acetone $(4 \mathrm{~mL})$ was treated with Jones reagent (5 drops) at room temperature for $20 \mathrm{~min}$. The work-up (EtOAc) gave a mixture of $5 \alpha-\Delta^{7}$-steroidal 3-ones (11 mg). The $\mathrm{Rt}_{\mathrm{R}}$ and MS data of $24 S$-Ethyl-5 $\alpha$-cholesta-7, $22 E$-dien-3-one by GC-MS were as follows : $\mathrm{Rt}_{\mathrm{R}}$ 1.23, EI-MS $m / z: 410\left(\mathrm{M}^{+}, 9\right), 395$ (2), $381(0.5)$, 367 (9), 349 (0.5), 325 (1), 312 (2), 298 (14), 283 (5), 269 (100), 257 (6), 255 (6), 253 (4), 244 (7), 229 (17), 217 (4), 213 (7), 201 (4), 187 (6), 185 (5), 175 (8), 173 (8), 161 (16), 159 (12), 149 (11), 147 (24), 137 (15), 135 (14), 123 (24), 121 (15), 119 (23), 109 (24), 107 (22), 105 (33). The $\mathrm{Rt}_{\mathrm{R}}$ and MS data of $24 \xi$-ethyl- $5 \alpha$-cholest-7-en-3-one by GC-MS were as follows : $\mathrm{Rt}_{\mathrm{R}} 1.33$, EI-MS $m / z: 412\left(\mathrm{M}^{+}\right.$, 68), 397 (33), 299 (5), 271 (100), 258 (14), 253 (11), 244 (30), 229 (63), 227 (9), 216 (11), 213 (36), 211 (12), 201 (20), 189 (9), 187 (19), 185 (10), 175 (14), 173 (18), 171 (22), 161 (40), 159 (23), 149 (23), 147 (36), 145 (21), 135 (41), 133 (30), 131 (26), 123 (36), 121 (43), 119 (62), 111 (31), 109 (32), 107 (50), 105 (67).

$2 \cdot 7$ Identification of the Steroids $X_{1}, X_{2}$ and $\mathrm{X}_{3}$ in the Seeds of Foxtail Millet

As previously described ${ }^{1}$, a $5 \alpha$-steroidal 3-one fraction was obtained from the seeds of foxtail millet. By use of the synthetic samples as standards, this fraction was reanalyzed by GC-MS.

\section{Results and Discussion}

To identify the steroid $\mathbf{X}_{1}$, a mixture of possible double bond isomers at the C-24(25), C-24(28)E and $\mathrm{C}-24(28) Z$ position was at first synthesized (Scheme 1). The steryl acetate mixture ${ }^{4)}$ was dihydroxylated and the resulting mixture of vicinal diols 1, without separation, was oxidatively cleaved to provide a known $3 \beta$-acetoxycholest-5en-24-one $2^{5}$. After exchange of the protecting group of 2 , the tetrahydropyranyl ether 4 was reacted with ethylmagnesium bromide, dehydrated with phosphorous oxychloride and deprotected to afford a sterol mixture 6. The mixture was subjected to Oppenauer oxidation to give a mixture of steroidal 4-en-3-ones 7 . It is well known that the Birch reduction of steroidal 4-en-3ones gives thermodynamically stable $5 \alpha$-steroidal 3-ones ${ }^{8}$. Thus, the steroidal 4-en-3-ones 7 was subjected to Birch reduction to provide a mixture of $5 \alpha$-steroidal 3-ones 8. The $\mathrm{Rt}_{\mathrm{R}}$ and MS data of the steroidal 4-en-3-ones 7 and the $5 \alpha$-steroidal 3ones 8 are summarized in Experimental section.

Having the mixture of the double bond isomers in hand, we reanalyzed the $5 \alpha$-steroidal 3-one fraction $^{1)}$ from the seeds of foxtail millet by GCMS. As expected, the MS data of the steroid $\mathbf{X}_{1}$ was in agreement with those of the C-24(25), C24(28) $E$ and C-24(28) $Z$ double bond isomers, but not with those of the C-23(24) double bond isomers. Among the former three isomers, the least component had the same $\mathrm{Rt}_{\mathrm{R}}$ as the natural product $\mathbf{X}_{\mathbf{1}}\left(R t_{R} 1.30\right)$, suggesting that the steroid $\mathbf{X}_{1}$ is a $\mathbf{C}-24(28) Z$ isomer, because among the sterol mixture 6 , the least component with $\mathrm{C}$ 24(28) double bond was found to be isofucosterol. Further, it is already found that its structurallyrelated steroid, 24-ethylcholesta-4,24(28)Z-dien-3one 10 occurs in the seeds ${ }^{1)}$. The steroid $X_{1}$ is most likely to be 24 -ethyl-5 $\alpha$-cholest-24(28) $Z$-en-3-one.

To synthesize this putative steroid, isofucosterol 9 is an ideal starting material, because it has the same carbon skeleton including the $Z$ configuration of 24-ethylidene moiety as the target steroid. Oppenauer oxidation of isofucosterol 9 gave 24ethylcholesta-4,24(28) $Z$-dien-3-one 10, which was subjected to Birch reduction to afford 24-ethyl-5 $\alpha$ cholest-24(28) $Z$-en-3-one 11 (Scheme 1). The $Z$ configuration of the steroid 11 was confirmed by a characteristic chemical shift of the proton at the C25 position $(\delta 2.829$, sept, $J=6.83 \mathrm{~Hz})$, which is in good agreement with that $(\delta 2.831$, sept, $J=6.9$ $\mathrm{Hz})$ of isofucosterol, but not with that $(\delta 2.198$, sept, $J=6.9 \mathrm{~Hz}$ ) of its $E$-isomer, fucosterol ${ }^{6}$. To confirm the $5 \alpha$-configuration of the steroid 11, the steroid 11 was hydrogenated and the resulting 

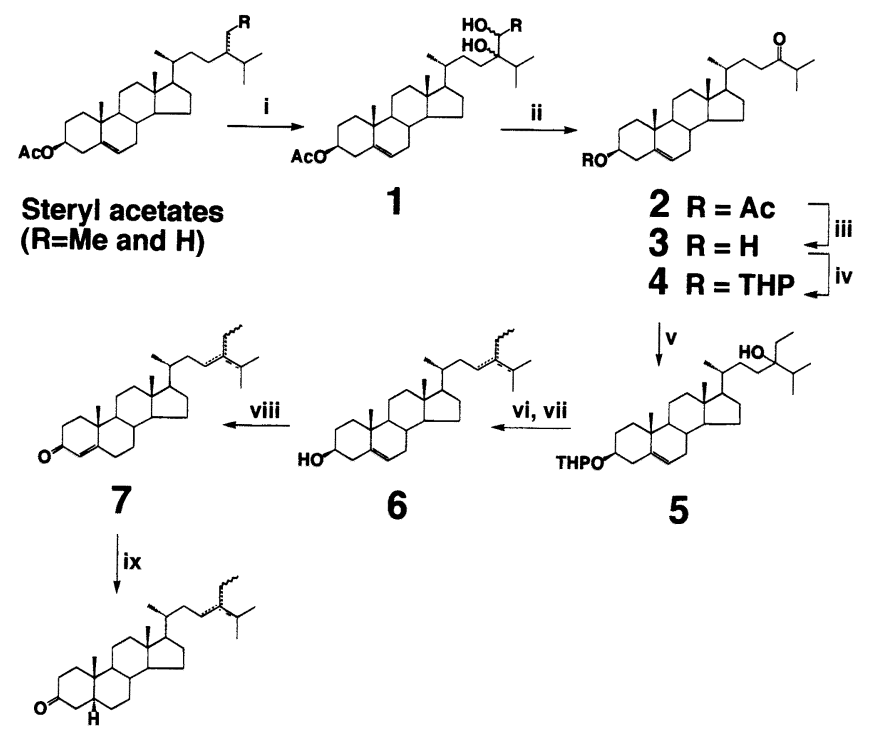

8

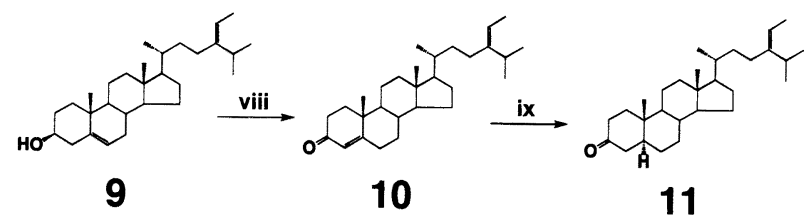

Scheme 1 Reagents and conditions : i , $\mathrm{OsO}_{4}, \mathrm{~N}$-methylmoropholine $\mathrm{N}$-oxide, $\mathrm{THF}-\mathrm{H}_{2} \mathrm{O}$, room temp., overnight, ii , $\mathrm{NalO}_{4}$, THF- $\mathrm{H}_{2} \mathrm{O}$, room temp., $2.5 \mathrm{~h}$; iii, $5 \%$ $\mathrm{KOH} / \mathrm{MeOH}$, THF, room temp., $1 \mathrm{~h}$; iv , 2, 3-dihydropyran, $p$-TsOH- $\mathrm{H}_{2} \mathrm{O}$, $\mathrm{CH}_{2} \mathrm{Cl}_{2}$, room temp., $1 \mathrm{~h}$; v, EtMgBr, THF, room temp., $1 \mathrm{~h}$; vi, $\mathrm{POCl}_{3}$, pyridine, room temp., $3 \mathrm{~d}$; vii, $2 \mathrm{M} \mathrm{HCl}$, THF-MeOH, room temp., $2 \mathrm{~h}$; viii, $\mathrm{Al}(\mathrm{i}-\mathrm{PrO})_{3}, 1$-methyl-4-piperidone, toluene, $110^{\circ} \mathrm{C}, 1 \mathrm{~h}$; ix, $\mathrm{Li}$, liq. $\mathrm{NH}_{3}-$ $\mathrm{EtOH} / \mathrm{THF},-78^{\circ} \mathrm{C}, 1 \mathrm{~h}$.

product was analyzed by GC-MS to be identical with 24-ethyl-5 $\alpha$-cholestan-3-one in terms of $t_{R}$ and MS data, which was derived from sitostanol by Jones oxidation ${ }^{2)}$. Discrimination between $5 \alpha$ - and $5 \beta$-steroidal 3-ones by MS data is already described in a literature ${ }^{3}$. Thus, the structure of the steroid 11 was unambiguously confirmed.

GC-MS analysis indicated that the steroid $\mathbf{X}_{1}$ with $\mathrm{Rt}_{\mathrm{R}} 1.30$ was identical with 24-ethyl-5 $\alpha$ cholest-24(28) $Z$-en-3-one $\mathbf{1 1}$ in terms of $t_{R}$ and MS data. To the best of our knowledge, the present work is the first identification of the steroid 11. In foxtail millet, this steroid is assumed to be derived from 24-ethylcholesta-4,24(28)Z-dien-3-one 10 by reduction of the $\mathrm{C}-4$ double bond, as it is already demonstrated in Arabidopsis thaliana L.9.10) and Catharanthus roseus ${ }^{11}$ that in an early part of a brassinolide biosynthesis, (24R)-24-methyl-5 $\alpha$ - cholestan-3-one is produced by enzymatic reduction of (24R)-24-methylcholest-4-en-3-one. Two steroids $\mathbf{X}_{2}$ and $\mathbf{X}_{3}$ with $\mathrm{Rt}_{\mathrm{R}} 1.23$ and 1.33 were identified as $24 \xi$-ethyl- $5 \alpha$-cholesta-7, $22 E$-dien-3one and $24 \xi$-ethyl-5 $\alpha$-cholest-7-en-3-one, respectively, based on direct GC-MS comparison with the synthetic samples. These two steroids were already found present in the herb Verbascum thapsus ${ }^{3}$.

(Received Jan. 28, 1999 ; Accepted Jul. 23, 1999)

\section{References}

1) S. Takatsuto, N. Kosuga, B. Abe, T. Noguchi, S. Fujioka, T. Yokota, J. Plant Res., 112, 27 (1999).

2) S. Takatsuto, B. Abe, unpublished result.

3) M.A. Khuroo, M.A. Qureshi, T.K. Razdan, P. Nichols, Phytochemistry, 27, 3541 (1988).

4) S. Takatsuto, K. Omote, Agric. Biol. Chem., 53, 
259 (1989).

5) D.R. Idler, U.H.M. Fagerlund, J. Am. Chem. Soc., 79, 1988 (1957).

6) L.J. Goad, T. Akihisa, "Analysis of Sterols", Blackie Academic \& Professional, London, (1997) p.357.

7) S. Takatsuto, E. Tsunokawa, T. Noguchi, S. Fujioka, J. Jpn. Oil Chem. Soc., 48, 347 (1999).

8) D.N. Kirk, M.P. Hartshorn, "Steroid Reaction Mechanisms", Reaction Mechanism in Organic Chemistry, Monograph 7, Elsevier Publishing Company, Amsterdam, (1968) p.197.

9) S. Fujioka, J. Li, Y.-H. Choi, H. Seto, S.
Takatsuto, T. Noguchi, T. Watanabe, H. Kuriyama, T. Yokota, J. Chory, A. Sakurai, Plant Cell, 9, 1951 (1997).

10) T. Noguchi, S. Fujioka, S. Takatsuto, S. Yoshida, A. Sakurai, J. Li, J. Chory, Abstract of the 32nd Annual Meeting of the Japanese Society for Chemical Regulation of Plants (in Japanese), Tokyo, p.93 (1997).

11) T. Noguchi, S. Fujioka, S. Takatsuto, S. Yoshida, Abstract of the Annual Meeting of the Japan Society for Bioscience, Biotechnology, and Agrochemistry (in Japanese), Nagoya, p.70 (1998). 


\section{[ノート］アワ種子中に含まれる新規ステロイド， 24-Ethyl-5 $\alpha$-cholest-24 (28) Z-en-3-one の合成と同定}

鳴海安久*1 . 渡辺剛*2 . 野口貴弘 ${ }^{* 2}$. 阿部文一 ${ }^{* 1}$

藤岡 昭 三*3 . 横田孝雄 ${ }^{* 4}$. 高津戸 秀*1

*1 上越教育大学自然系化学教室 (广 943-8512 新潟県上越市山屋敷町 1)

*2 夕マ生化学 (T 163-0704 東京都新宿区西新宿 2-7-1)

*3 理化学研究所植物機能研究室 (T 351-0198 埼玉県和光市広沢 2-1)

*4 帝京大学バイオサイエンス学科（テ 320-8551 栃木県宇都宮市豊郷台 1-1)

アワ (Setaria italica Beauv.) 種子中から検出された 3 種の微量な $5 \alpha$-ステロイド系3-オンの構造決定を行っ た。これらを同定するために、24-ethyl-5 $\alpha$-cholest-24（28）Z-en-3-one およびその炭素- 炭素二重結合異性体 をイソフコステロールから合成した。合成標品との GC-MS による直接比較により，一つを 24 -ethyl-5 $\alpha^{-}$ cholest-24 (28) Z-en-3-one とはじめて同定した。さらに, 残りの 2 種も $24 \xi$-ethyl-5 $\alpha$-cholesta-7,22E-dien-3one および $24 \xi$-ethyl-5 $\alpha$-cholest-7-en-3-one と同定した。

(連絡者：高津戸 秀) Vol.48, No.11，1307（1999） 